\title{
The potential of history textbooks and curriculum reform in Iraqi Kurdistan within a conflict transformation frame: dealing with the past from a processual and dynamic perspective
}

\author{
Jordi Tejel
}

To cite this article: Jordi Tejel (2015) The potential of history textbooks and curriculum reform in Iraqi Kurdistan within a conflict transformation frame: dealing with the past from a processual and dynamic perspective, Ethnic and Racial Studies, 38:14, 2569-2583, DOI: $10.1080 / 01419870.2015 .1061134$

To link to this article: http://dx.doi.org/10.1080/01419870.2015.1061134

Published online: 28 Sep 2015.

Submit your article to this journal $\pi$

山 Article views: 13

Q View related articles $₫$

View Crossmark data $\nearrow$ 


\title{
The potential of history textbooks and curriculum reform in Iraqi Kurdistan within a conflict transformation frame: dealing with the past from a processual and dynamic perspective
}

\author{
Jordi Tejel \\ (Received 29 June 2014; accepted 27 April 2015)
}

\begin{abstract}
As of 2015, Kurds in Iraq remain masters of an autonomous region, considered by many as a de facto state, and important brokers within the Iraqi political arena. Prompted by these 'gains', many observers and researchers have been inclined to announce the imminent establishment of a Kurdish state. However, this article argues that scholars should be cautious before pronouncing a complete break between the Iraqi state and the Kurds. It shows from a processual and dynamic approach how and why scholars should go beyond the 'assimilation versus resistance' dichotomy in order to better grasp the relations between 'majorities' and 'minorities' in Iraq and in the Middle East, in general. Yet, acknowledging the present deadlock, it explores the conditions that may allow history textbooks to play a role in easing ethnic relations by rewriting Kurdish history. It could lead to the emergence of a new, collective, albeit multiple, Iraqi history.
\end{abstract}

Keywords: Kurds; minorities; Anfal; victimhood; textbook reforms; conflict transformation

In the aftermath of the American invasion of Iraq in 2003 and the subsequent fall of Saddam Hussein's regime, Western journalists, think tanks and scholars, as well as Kurdish media outlets, foresaw the establishment of a Kurdish state in present northern Iraq. Since then, the number of reports and articles speculating on the possible creation of a Kurdish state has dramatically increased (Lowe and Stansfield 2010; Gunter 2011; Gunter and Ahmed 2013). Furthermore, as the Iraqi army abandoned its positions following the Islamic State of Iraq and al-Sham's (ISIS) incursion into Mosul in June 2014, Kurdish security forces advanced beyond the Kurdistan Regional Government (KRG)-controlled areas. Subsequently, Massud Barzani, president of the KRG, made a call for an independence referendum within 'a few months'. Although the referendum has been postponed, the post-Saddam era and the unexpected consequences of the Syrian uprising of 2011 have purportedly created a unique opportunity for the Kurds where 'the great losers of the Ottoman Empire could be winners' (Hirst 2013).

However, despite this unprecedented 'opportunity' and the everlasting tensions between the KRG and the Iraqi government over the implementation of the 2005 Iraqi Constitution, Kurds are not overtly keen about the concept of independence. According to the latest polls conducted in Iraqi Kurdistan in September 2012, only $56.3 \%$ of the respondents answered 'yes' to the question '[D]o you think it is a 
good time for Kurdistan Region to proclaim independence?' (Wing 2012). Following ISIS attacks in Shingal and the advance of its militias towards Erbil in August 2014, there has been no significant political mobilization in Iraqi Kurdistan regarding independence. All in all, it seems that for Iraqi Kurds, independence can wait. This raises one key question: how can we account for these 'surprising' attitudes with regards to Kurdish aspirations in Iraq?

For many years, scholars and observers have studied the evolution of the Kurdish issue, and of minorities in general, through the lens of the 'assimilation versus resistance' frame, while neglecting a wide range of individual and collective strategies that warrant further attention. In other words, it is preferable to avoid the overdetermination of opposing logics and the assumption that all such situations are competitive (Bajoit 1988, 325-345). While the articulation of identities and interests is without a doubt necessary to analyze ethnic-based movements, scholars should also consider subjective perceptions of social relations (present experience, collective memories, etc.) that may lead social actors to choose a strategy that might be perceived as 'surprising' from the 'outside' (Koselleck 1990).

Hence, for the purpose of an initial assessment and in order to better grasp the relations between 'majorities' and 'minorities' ethnic and/or religious groups over time, researchers should study this issue from a processual, dynamic and relational approach (Newbury 1988) that encapsulates three key principles. First, majority and minority groups are not always and everywhere opposed. The use of a long-term perspective allows us to identify periods in which minority members participate in the economic and political life of a given society, and cooperate with other political forces (both within the government and the opposition), as well as periods of extreme state violence against that very minority.

The second principle is that, as a consequence, the relationship between majorities and minorities then becomes a part of a dynamic process in which both continuity and change must be taken into account. Minority populations are constantly negotiating their individual and collective identity (ethnic and religious boundaries, relations in different social spaces) with regard to the state and to other social groups. Therefore, ethnic identities can be 'activated' or 'deactivated' at the political level, depending on the context and the subjectivity of the actors.

Finally, although regimes and minority groups project an image of homogeneity to the outside world, the actual practice or routine performance of state actors and agencies in various arenas, as well as the contradictions that exist within minorities, often counter this image (Migdal 2001, 16). In some cases, sections of the state ally themselves with parts of the minority in order to overcome state deficiencies. Similarly, ethnic movements struggle to impose their values on society as they attempt to impose a hierarchy between groups, as well as to exert their influence in different arenas where other actors are already present.

Taking these principles into consideration, a brief historical survey of relations between the main Kurdish political parties and the different Iraqi regimes will allow me to prove that, more often than not, tensions have gone hand in hand with political negotiations and interethnic cooperation. In that respect, minorities, be they ethnic or religious, should not be analyzed only as 'victims' and/or passive actors; they actively 
contribute to transform and redefine the terms and parameters around 'conflicts of differentiation'.

In the second part of my paper, I suggest that, broadly speaking, the minority issue in Iraq, as elsewhere, 'proves to be closely related to the issue of democratization and the respect of the rule of law' (Picard 2012, 346). Obviously, certain political actors, Kurdish and Arab alike, are expected to play a significant role in easing the tensions between the KRG and the central government in Baghdad, thereby ensuring the emergence of a new 'social contract'. As a historian, however, I shall focus on how educational reforms, and in particular history textbooks, may play a role in easing ethnic and sectarian relations in Iraq. As Falk Pingel (2008) suggests, (historical) truth cannot always be negotiated and, clearly, historical narratives are not the only or the most important domain for a conflict resolution frame. However, dealing constructively with diversity, collective victimhood and lasting conflicts is a matter of both 'hardware', such as constitutions and institutional design, and 'software', such as forms of discourse, historical narratives and feelings of trust (Rose, Mishler, and Haerpfer 1998; Mattes 2007). Thus, there is a 'hardware' question: who has jurisdiction over education and how decentralized is it; and a 'software' question: is education taught in a way that reinforces the resistance/assimilation frame? Ultimately, both questions are interconnected, for no answer to the former will work if it is not accompanied by creative attention to the latter.

Yet while the conflict resolution approach seeks to put an end to conflicts through the act of attending to basic needs of the conflicting parties such as security and identity, this paper suggests, partly drawing on the conflict transformation paradigm (BuckleyZistel 2008; Kriesberg 2007; Lederach 1997; Mitchell 2000; Strömbom 2013), that conflicts around identity are to be understood as part and parcel of the social construction of any society. Thus, local and international actors must seek innovative ways to deal with ethnic and sectarian conflicts in Iraq, because tensions around the official identity of the Iraqi state and around memories of violence have shaped relations between various Iraqi sectors since its inception (Davis 2005).

In that sense, this article pays particular attention to what extent teaching history may become a particularly important ingredient of the new 'software'. Interestingly, keeping with a processual and dynamic approach to conflict, the conflict transformation paradigm emphasizes the importance of change in attitudes towards both the adversary and one's own group. In other words, the process towards conflict transformation can begin only when the visions and perceptions of the 'we-group' and the 'other' undergo a change (Buckley-Zistel 2008, 21).

It is only when the Kurds and all Iraqi groups will be able to elaborate their own narratives and undergo a process of digging into a much more complex past, as well as a process of de-victimization, an 'official Iraqi history' (seen as a unitary component of the Iraqi identity) will be likely to emerge. In that sense, and contrary to the belief that federalism tends to foster existing divisions through the hardening of identities (Brancati 2006; Bunce 1999), I shall argue that federalism and KRG's full competence over education may in fact offer prospects for such developments, provided that all levels of society, from elites to grass roots, as well as third parties to conflict, are involved. 


\section{A processual and dynamic approach to the Kurdish issue}

Due to space constraints, I will not be able to recall all historical landmarks with regards to the Kurdish issue, since the creation of the Iraqi state until the fall of the Ba'thist regime in 2003. Instead, through the review of some significant developments, I shall stress two ideas. On the one hand, as tempting as it is to suggest a cohesive historical narrative in which Kurds, portrayed as a monolithic group, appear as victims of the regime, one must acknowledge that Kurds have displayed different strategies vis-àvis diverse Iraqi actors in order to renegotiate their individual, as well as collective place in Iraq's social and political hierarchy. On the other hand, and related to the previous point, the conflict between Kurdish movements and various Iraqi actors has been undergoing constant change, with both peaceful and violent transformations.

According to Article 64 of the Treaty of Sèvres (1920), the Kurdish peoples of present-day south-eastern Turkey addressed the Council of the League of Nations to show that a majority of the population in those areas desired independence from Turkey. Ultimately, the Kurds inhabiting the former Ottoman Vilayet of Mosul (northern Iraq) were allowed to adhere to such an independent Kurdish state. However, diverse international, regional and local dynamics, such as the Kemalist revolt initiated already in 1919, divisions among the Kurds in Turkey, and the increasing tensions between France and Great Britain over territorial claims, rendered the Treaty of Sèvres futile. In 1923, the Treaty of Lausanne acknowledged the territorial sovereignty of the new Turkish state and abandoned any promise of an autonomous Kurdistan and/ or any provision to secure 'minority rights' for Kurds within Turkey. The Treaty, however, did not settle the future of the Vilayet of Mosul and left it to be decided in direct negotiations between Turkey and Britain.

In parallel, in 1919, the British created an autonomous 'Southern Kurdistan' in today's Sulaimaniyya province, which escaped from Baghdad's influence. In 1922, a joint Anglo-Iraqi statement recognized the right of the Kurds living within the boundaries of Iraq to set up a Kurdish government (Hukumet). Furthermore, the Council of the League of Nations eventually awarded Mosul to Iraq in December 1925, subject to certain guarantees with regard to respecting the Kurds. Great Britain's decision in February 1929 to renounce its Mandate on Iraq and let the country gain its independence by negotiating a new treaty wherein no mention was made regarding Kurdish autonomy provoked the largest urban mobilization in Kurdistan during the period of the Mandate (Tejel 2008, 537-552).

Despite its shortcomings, the parliamentary system established during the monarchy (1920-1958) allowed for the expression of plural views and the emergence of a public sphere that was not completely controlled by the British nor the government in Baghdad (Bashkin 2009). Not only did diverse blocs (e.g. pro-autonomy and proBaghdad) emerge in Kurdish cities such as Sulaimaniyya, but also diverse sectors of Kurdish society sought to establish non-oppositional relationships with the Iraqi government. Thus, several Kurdish notables and tribal chiefs were integrated into Iraqi official life as ministers, deputies, mutasarrifs or as high-ranking officers, such as General Bakr Sidqi. ${ }^{2}$

In the same vein, large numbers of Kurds, Arabs, Assyrians and Jews joined nonsectarian political groups such as the Iraqi Communist Party (ICP) and other smaller 
Iraqi nationalist parties to struggle for Iraq's total independence. ${ }^{3}$ The Kurds joined the ICP in such proportions in the post-Second World War period that Hanna Batatu (1978, 657-705) considered these years as the period of Kurdish ascendancy in the ICP. Seemingly, during the anti-British uprising (Wathba of 1948), the recently established Kurdistan Democratic Party (KDP) actively cooperated with the ICP and the Democratic National Party (Barzani 2003, 263-264).

Yet the most important episode of cooperation between the Kurds and the Iraqi government came in 1958 as Qasim, the president of the first Iraqi Republic, opened the door to the recognition of Kurdish 'national rights' in Article 23 of the Provisional Constitution. Threatened by both the Ba'thist party in Iraq and the increasing regional ambitions of Gamal Abdel Nasser, Qasim sought to secure the stability of his government using the support of the communists and the Kurds. Consequently, many Kurds were appointed to high offices, while Kurdish publications circulated freely and a special Kurdish section on radio and television broadcasts was established. Moreover, during Qasim's era, Kurdish was gradually adopted as the language of instruction at the intermediate and secondary levels in Kurdish areas, although curriculum development remained centralized.

However, relations between Qasim and the KDP rapidly deteriorated. In July 1961, Barzani submitted a memorandum to the government, demanding a substantial degree of autonomy for the Kurdish region. The government rejected it, afraid that such plan might induce the Shia to demand a similar status, and the relations with the KDP worsened to the extent that a nine-year war (with brief interruptions) broke out, between the central government and the Kurds. This new cycle of conflict between the Kurdish movement and the Iraqi government paved the way for a short cooperation in 1963 between the KDP and the Iraqi opposition, mainly the Ba'th party, despite its panArab leaning. ${ }^{4}$

Between 1958 and 1968, Iraq witnessed an era marked by successive military coups and a deeper fragmentation of the Iraqi army. Notwithstanding the instability of the political system and the succession of diverse Iraqi leaders, Qasim's recognition of Kurdish 'nationality' altered the equation between Kurds and the Iraqi state altogether. Although during this decade pan-Arabism seemed to dominate the Iraqi political field, the existence of a distinct Kurdish identity and even the principle of a certain degree of administrative autonomy were accepted, albeit with limitations, by the main Iraqi parties, leftists and pan-Arabists alike.

Paradoxically, this symbolic gain did not bring an end to a heavy state repression of some Kurdish areas. In fact, violence from both camps (the state and Kurdish guerilla) became one of the tools used to renegotiate the terms of the Kurdish equation. Thus, for instance, taking advantage of the alliance with Iran (backed by Israel and the USA), Barzani was able to challenge Iraqi forces militarily, and severely weaken the state's stability. Hence, the Ba'thist party in power since 1968 negotiated an autonomy agreement with the Kurds that came into existence in 1970. ${ }^{5}$ By 1973, however, relations deteriorated and the Iraqi government reneged on its commitments; in turn, the KDP resumed its insurgency.

Despite some tactical contacts made by the two camps throughout the 1980s, the 1970-1973 talks were the last true negotiations between Baghdad and the Kurds on self-governance in Iraq. Furthermore, within the context of the Iran-Iraq war, the 
Ba'thist regime launched a massive coercive campaign, Anfal, against Kurdish rebels between 1986 and 1988. Probably the most famous of these reprisals was the attack on the town of Halabja in March 1988, in which some 5,000 civilians were killed when Iraqi warplanes dropped mustard gas and other chemical weapons on the city. Although the actual figures of victims of the campaign are an issue of contention, Human Rights Watch has a list of 50,000 names that have been found in the regime's own documents (Middle East Watch 1993).

The effective self-government that the Kurds have enjoyed in northern Iraq since 1992 was the result of Saddam Hussein's decision to invade Kuwait, triggering a broad international military campaign to drive his forces out. Although the US forces did not help the Kurds to take control of the three main Kurdish provinces, the American government established a 'safe haven' and a no-fly zone in northern Iraq. In October 1991, Iraqi forces and state employees unilaterally withdrew from Kurdistan, thereby allowing the two main political parties to organize free elections and set up a regional government. The US invasion of Iraq in 2003 and the subsequent fall of the regime then reinforced Kurdish autonomy and the role of the Kurdish parties within the Iraqi political arena in the aftermath of the war. Significantly, Article 117 of the 2005 Iraqi Constitution recognizes the region of Kurdistan, along with its authorities, as a federal region, thus enshrining the principle of federalism in the country's basic law.

Obviously, the aim of this brief historical overview of the state-Kurds relations was neither to deny the suffering of different sectors of the Kurdish society throughout the twentieth century, nor to suggest that those relations were uncomplicated. It rather sought to offer a much more nuanced and dynamic perspective of those relations. Concomitantly, it intended to show that there is enough 'material' to feed the 'software' part (including a new Kurdish historical narrative) as a necessary step to move towards a transformation of extant conflicts around the traumatic past chapters and the identity of the Iraqi state.

\section{Towards a new historical narrative?}

Louis Kriesberg, one of the proponents of the conflict transformation paradigm, argues that a process of de-escalation reduces the severity or scope of a conflict. Interestingly enough, in Kriesberg's view (1998), de-escalation does not always lead to the resolution of a conflict, but always precedes conflict resolutions. Similar to the "hardware / software' metaphor, a de-escalation process also involves a number of factors linked to different levels of political and social intervention. Thus, besides some conciliatory gestures as well as organizational dynamics, establishing and sharing of certain norms over the course of the conflict may encourage de-escalation. Furthermore, intermediaries acting as mediators, and third parties can play an important role in promoting de-escalation. For the purpose of my argument, however, I shall focus on the extent to which history textbooks may play a significant role in the process of de-escalation through the transformation of perceptions about the past, the 'other' and, crucially, about 'oneself'.

Indeed, several authors have highlighted the reconciliatory potential of teaching history in post-conflict societies. The reason is that textbooks, in general, are thought of as a reflection of recognized and officially selected knowledge that everyone 
in a given society is expected to know (Apple 1993, 46). Yet it is also acknowledged that textbooks are ambivalent. On the one hand, in both authoritarian and democratic countries, history textbooks tend, albeit to a different degree, to trace specific selfimages and images of alleged 'other' back into the past and to lend them specific validity, in specific cases to the point of constructing and legitimizing national superiority, collective victimhood, or hostility (Lässig 2013, 1).

On the other hand, fear, prejudice and bias of the adults are often passed on to a new generation through history textbooks, which contribute to maintain conflictual relations and block the development of cooperation within and between states (Dorschner and Sherlock 2007, 276). In sum, a reform of the history curriculum is not the solution per se in post-conflict contexts, for history textbooks can both 'reproduce the conditions which underlie civil conflict' and 'help transform society by challenging the deep-rooted prejudices and inequalities at the heart of the conflict' (Leach and Dunne 2007, 11).

Although the actual impact of educational reforms on post-conflict contexts is hardly measurable, generally speaking, there are two opposed views on this issue. Some authors tend to stress that a positive outcome of such initiatives is rather rare (Pingel 2008; Torsti 2007). To Johan Franzén, a key factor in explaining the exceptionally rare instances of success in reforming history curriculum is the contradictory expectations of the authorities and third parties. Thus, in conflict-ridden countries such as Iraq, the new authorities not only expect that the history curriculum explains what happened but that 'it is also charged with presenting a new narrative at odds with the old one, a narrative whose goal it is to unite the fragmented country' (Franzén 2012, 32). Northern Ireland and Bosnia are often cited as failed attempts to reconcile old 'enemies', for the segregation of education is viewed as pivotal in sustaining the conflict; in the long-term, "nationally-divided schooling and the teaching of history through "us" and "them" as hostile groups, and with great emphasis on wars, can become a central factor in maintaining conflict' (Torsti 2007, 92). From this viewpoint, Iraqi federalism and the KRG's competence over the Kurdish educational system should allegedly lead to a hardening of ethnic divisions and, ultimately, to the division of the Iraqi state.

Some initiatives are nonetheless regarded as successful. Germany and France, once 'old enemies', have produced common textbooks that are officially approved for regular use in schools in both countries. In Finland, after the Second World War, civil society groups played a relevant role in bridging narratives about the civil war that had confronted the Red troops and the White armies. In Spain, the representation of the period between 1931 and 1975 in history textbooks has changed in a positive way (Valls 2007, 155-174). Finally, experts agree that positive changes, if any, cannot be observed in the short term. In fact, a positive outcome was possible only after long periods of bargaining, debates, ups and downs, and contradictory policies (Pingel 2008, 191).

Having underlined the need of a processual and dynamic approach to both long-term historical relations between 'majority' and 'minority' groups and ethnic conflict, I suggest in what follows that a focus on process (a dynamic interplay between actors and structures in conflictual change) rather than outcome may allow us to advance further in understanding the role of textbooks in post-conflict contexts. Tenets of the 
conflict transformation paradigm and experts on curriculum reform alike stress the importance for the entire society to get actively involved (Lederach 1997, 17) from elites to grass roots, as well as third parties to conflict, in order to achieve the goal of reducing the conflict.

In some cases, such as the UNESCO-UNICEF activities in Iraq or the activities in Bosnia and Herzegovina following the Dayton Agreement, groups of local participants were founded by foreign agencies that provided funding and an agenda. Yet research on textbook reform underlines that these attempts can only succeed if the 'target groups' become the 'owners' of the process (Stöber 2013, 45). The question is, therefore, whether the conditions are ripe for a joint initiative involving local and international stakeholders to pursue such reforms in Iraqi Kurdistan.

\section{Education reform in Iraq since 2003}

As elsewhere, uniform mass education, which was introduced in Iraq in the 1920s and 1930s, was used to 'build' a nation. Consequently, history textbooks were used to contribute to an apparent sense of unity, although the ingredients that compose Iraqi identity varied according to the political agenda of the incumbent regime. Following Qasim's endeavours to shape an inclusive Iraqi identity, as opposed to a national identity based on Arabness alone, a new stage in officially sponsored state history came to reality as the Ba'th Party rose to power in 1968. In an attempt to accommodate panArabism and Iraqi-ness, Ba'thist intellectuals, historians and archaeologists began propagating the idea of an 'Iraqi people' that had existed since the beginning of time and for which Arab-Islamic civilization was just one of many great civilizations to have existed in 'Iraq' (Baram 1991, 100). If Iraqi people had always been 'there', there was no basis for particularist claims from some 'Iraqi' groups such as the Kurds.

The de-Ba'thification policy promoted by the Coalition Provisional Authority (CPA) in 2003 opened the door to a shift in history writing. On the one hand, CPA officials favoured the production of new textbooks, complete with a USAID-approved 'reinterpretation of Iraqi, Arab, and Islamic history'. On the other, education reforms were aimed at the replacement of an academic system perceived as dominated and shaped by the primacy of 'ideology' with a new system founded on the values and ethos of the liberal arts (Méténier 2006). However, all these efforts were implemented from a top-down perspective and, more importantly, without the real intellectual involvement of Iraqi scholars.

The immediate outcome was a series of updated textbooks that had simply deleted all sections deemed 'controversial', including references to the 2003 US-led invasion, sectarian differences between Shias and Sunnis, and the Kurdish claims for autonomy. Further haphazard changes followed from 2008 onwards due to growing criticism from various sectors, including international organizations such as UNICEF (Osman 2015, 190).

Meanwhile, if textbooks in Kurdistan region did not undergo any significant change between 1991 and 2003, the textbooks produced by the KRG were modified, if not reconstructed, after the fall of the regime to reflect the Kurds' vision of nation building (Kirmanj 2013, 86). In doing so, 'new history textbooks lay emphasis on Kurdistan region as an entity rather than on Iraq as a whole, thereby serving an explicitly 
nationalist political project' (Osman 2015, 191). The focus on Kurdish historical landmarks is exacerbated by the fact that none of the Kurdish essential historical events (i.e. the collapse of the Barzani revolt in 1975 or the Anfal campaign) occupies a significant space in Iraqi textbooks, apart from the 1991 uprising, in which Shia Arabs also participated (Kirmanj 2013, 87). Although current Iraqi textbooks no longer contain pejorative terms with regard to Kurds, they are still written from a pan-Arab and pan-Islamic perspective.

Apart from differences around the 'identity' of the Iraqi state and its 'citizens', memories of massive violence remain the bone of contention between diverse sectors of Iraqi society (Al-Marashi and Keskin 2008, 246). Following the establishment of the autonomous region in Iraqi Kurdistan, numerous studies, as well as political actors, have tried to prove that the Kurds have been the victims of a systematic genocidal policy since the creation of the Iraqi state. Although such political usage of historical memory may be understandable, some scholars point out that this dynamic is hardly conducive to reconciliation (Franzén 2012, 33).

Furthermore, the 'natural' interest in the Anfal campaign has led to two parallel distorting effects. On the one hand, the Anfal survivors (e.g. lower-class rural people and, in particular, women) have been neglected by the hegemonic political discourse of 'national suffering' produced by academics and non-academics, both groups pertaining to the well-educated, middle and upper classes of Kurdish society. Crucially, the 'official' history of Anfal omits the role of Kurdish militias collaborating with the Ba'th regime and being actively involved in the destruction of Kurdish villages (Mlodoch 2012, 218).

On the other hand, this hegemonic political discourse and the rewriting of history on Anfal tends to link the genocidal persecution of 1988 to present political issues at stake, such as the future of Kirkuk and of other 'disputed territories' between the KRG and the Iraqi government. From that perspective, and according to the main Kurdish political parties, the Anfal campaign tells us that 'any Arab regime's purpose is to exterminate the Kurdish nation'. Hence, it makes sense to teach 'the people what the word genocide basically means, where it comes from, and that in Kurdistan genocide is not only an experience situated in the past but a lasting (and continuing) threat' (Fischer-Tahir 2012, 243).

\section{Social and political facilitator conditions}

Despite all these undisputed developments, three intersecting processes stemming from three different levels of intervention - political, grass roots and international - could pave the way for a curriculum reform. As we shall see, taken together, these three levels can allow for a re-conceptualization of Kurdish narratives about the past as a necessary step to transform the attitudes towards both the adversary and one's own group. Before this is achieved, any attempt to bridge Iraqi groups' histories may not be fruitful.

At a political level, ISIS military offensive during the summer of 2014 has ultimately favoured a political rapprochement between the KRG and the Iraqi government. While Barzani postponed the announced independence referendum, Nouri al-Maliki was replaced by the more consensual figure of Haider al-Abadi as Iraqi prime minister in 
September 2014. Subsequently, the two entities have reached a preliminary agreement on sensitive issues such as oil wealth and national budget distribution. Internally, ISIS threat has sparked a revival of tensions between the two main Kurdish political parties, the KDP and the Patriotic Union of Kurdistan (PUK), thereby hindering for the time being any unitary project for Kurdish independence.

Furthermore, in spite of all alarm bells about the unstoppable march of the Kurds towards independence, elite discourse about the place that Kurds must occupy in Iraq is not clear. First, the approach taken by the KRG textbooks to the concepts of Kurdish and 'Kurdistani' national identity - territorial rather than ethnic - has not been clearly articulated yet. Second, while sporadically promoting the notion of panKurdism, KRG textbooks still consider Kurdistan region as a part of Iraq, and Kurds as its citizens. More importantly, their primary focus regarding all KRG history and social studies textbooks remains the Kurdistan region in Iraq (Kirmanj 2014, 376). Finally, the Kurdish history curriculum, just like before, still focuses mainly on the history of Islam. In that sense, the history curriculum in Kurdistan region cannot be considered as a real 'threat' to the unity of the Iraqi state. ${ }^{6}$

At a grass-roots level, testimonies and narratives of Anfal survivors are increasingly competing with and challenging the hegemonic Kurdish national narrative on the Anfal (Mlodoch 2012, 221). In March 2005, for example, the survivors of the chemical attack on Halabja expressed anger and bitterness about the lack of assistance by holding a demonstration against the official anniversary celebration and burning down the memorial of Halabja in the course of the protests. In April 2009, the first corpses of Anfal victims found in a mass grave in Najaf were buried in the city of Rizgary. During the ceremony, the survivors and their descendants protested sharply against the absence of senior Kurdish politicians and criticized the political parties for not bringing the collaborators to justice (Mlodoch 2012, 222).

Finally, the involvement of third actors in reforming the education system in Kurdistan region is already a fact. Since 2005, UNESCO has taken the lead of international efforts geared towards the 'modernization and reconciliation' in Iraqi society through the development of a new Iraqi curriculum and new textbooks based on the values and orientation of the Iraqi Federal Constitution (2005) and the Iraqi National Education Strategy (2011). As a result, local stakeholders have committed themselves to developing and implementing new Iraqi curricula, which ought to strike a balance between a 'centralized' curriculum and 'decentralized' models, where local communities and/or schools are granted certain autonomy regarding the curriculum. In other words, the new general framework while stressing what they have in common in Iraqi curriculum development, leaves the space for the 'Kurdish Region's specificities' (UNESCO 2012, 9). The involvement of third actors within the Iraqi educational debate, including nongovernmental organizations such as the US Institute of Peace may also help to explain some recent positive developments. Thus, in 2012, a school textbook deemed offensive to Christians was removed from the education system in Kurdistan region.

Will all these ongoing dynamics lead to the resolution of the current conflict between the Kurdish parties and the Iraqi government, on the one hand, and between all Iraqi political blocs, on the other? The point made here is somewhat different. Political rapprochement between the main political stakeholders (KRG and central government), grass-roots developments and the involvement of third actors could pave the way to 
a de-escalation process while allowing mutual acceptance of contention issues, or at least a transformation of the parameters of the conflict. Undoubtedly, such process would take time and it would be tied to contingencies, such as political instability and warfare, dynamics that of course go well beyond the debates on education reform.

\section{Conclusion}

As of 2015, Kurds in Iraq remain masters of an autonomous region, considered by many as a de facto state, and important brokers within the Iraqi political arena. Prompted by these gains, many observers have been inclined to announce the imminent establishment of a Kurdish state. However, as I have sought to demonstrate, scholars should be cautious before pronouncing a complete break between the Iraqi state and the Kurds for at least two reasons. On the one hand, Kurdish individuals and groups participated in political and social life in Iraq throughout the twentieth century. Against this backdrop, the implication of some important Kurdish figures within the Iraqi state apparatus following the fall of the Ba'thist regime can hardly be considered as an unprecedented development.

On the other hand, the relationship between Kurds and Arabs has not always and everywhere been one of atavistic enmity, as some scholars, observers and political actors have depicted. It is certain that as various state elites embraced 'unanimist' ideologies since the 1960s, such as pan-Arabism, and built up authoritarian regimes in Iraq, ethnic identity became relevant in the eyes of Kurds and other 'minority' groups. The result is that Kurdish and Arab political elites were unable to set the basis for a new social contract because both sides remained stuck, through a dynamic process of mimesis, with homogenizing fictions about their respective groups as well as with their collective claims.

Interestingly, however, despite the over-representation of this conflict, the Kurds have not historically called for secession. On the contrary, the Kurds in Iraq have aimed to enhance their cultural rights and political autonomy within the existing political boundaries inasmuch as their collective identity is recognized and promoted in constitutional law. In this sense, it seems worthwhile for our understanding of strategies used in their respective states by ethnic minority groups to surpass the traditional conceptual dichotomy of 'assimilation versus resistance'.

Finally, I have argued that the principle of federalism in Iraq will be successful in allowing peaceful coexistence between the diverse segments that constitute the Iraqi society, provided that real trust exists between elites, accompanied by a clear commitment to democratic institutions and processes, and the rule of law. In that respect, the writing of a new collective, albeit multiple, history may help in creating such psychological and conciliatory conditions. However, as Johan Franzén $(2012,45)$ rightly points out, two dynamics need to go hand in hand. First, a political agreement has to be reached on Iraq's future between the diverse political actors before any hope of achieving a 'new Iraqi history' can become a realistic goal. Second, only when communities and groups that have seen themselves as victims of political persecution for decades become able to develop and sustain their historical narrative for a significant time, will it be possible for them to take steps towards political and historical reconciliation. 
The definitions of 'Iraqi national identity' and grievances about state repression have been issues of contention since the establishment of the Iraqi state. In the future, like in the past, power relations will continue to determine the weight of each of the ingredients that constitute Iraqi identity - Arab, Muslim, or Iraqi - and the prominence of certain traumatic memories. In that sense, the KRG's full competence over education in the Kurdistan region entails risks and opportunities at the same time. While Kurdish history textbooks tend to serve a political agenda - building a nation state within a nation state, according to Sherko Kirmanj (2014) - I have shown that, on the one hand, the elite discourse about the final position of Kurds within the Iraqi state is not clear yet, and, on the other hand, some developments stemming from different levels (political, grass roots, international) might provide the impetus for a de-escalation of conflict. This should include a preliminary de-victimization of collective memories by the KRG and the central government, or, at least, a new transformation of the parameters of the conflict through curriculum reform.

\section{Disclosure statement}

No potential conflict of interest was reported by the author.

\section{Funding}

This work was supported by the Swiss National Science Foundation [grant number PP00P1_152935].

\section{Notes}

1. In this paper, I use Brubaker's $(1996,60)$ definition:

A national minority is not simply a group that is given by the facts of ethnic demography. It is a dynamic political stance, or, more precisely, a family of related yet mutually competing stances, not a static ethno-demographic condition.

2. Between 1940 and 1950 , the percentage of Kurdish high-ranking officials within the Iraqi state reached 18\% (Marr 1985, 144).

3. National Archive, Foreign Office (hereafter NA, FO): 371/98738. British Embassy. Baghdad, 21 May 1952.

4. French Diplomatic Archives in Nantes (CADN): 1422. French Embassy (Baghdad) to Ministry of Foreign Affairs (Paris). Baghdad, 17 January 1963.

5. For the content of the settlement, see NA, CO 17/1237. 'The Ba'athist Government's Settlement with the Kurds.' Diplomatic Report No. 234/70. Baghdad, 2 April 1970.

6. Interview with Prof. Khawla Khanekah, University of Salahaddin, Erbil, 15 January 2015.

\section{References}

Al-Marashi, Ibrahim, and Aysegul Keskin. 2008. "Reconciliation Dilemmas in Post-Ba'athist Iraq: Truth Commissions, Media and Ethno-sectarian Conflicts." Mediterranean Politics 12 (2): 243-259. doi:10.1080/13629390802127562. 
Apple, Michael. 1993. Official Knowledge: Democratic Education in a Conservative Age. New York: Routledge.

Bajoit, Guy. 1988. "Exit, Voice and Loyalty ... and Apathy. Les réactions individuelles du mécontentement [Individual Reactions from Discontent]." Revue française de sociologie 29 (2): 325-345.

Baram, Amatzia. 1991. Culture, History and Ideology in the Formation of Ba'thist Iraq, 1968 1989. New York: St. Martin's Press.

Barzani, Masoud. 2003. Mustafa Barzani and the Kurdish Liberation Movement (1931-1961). New York: Palgrave.

Bashkin, Orit. 2009. The Other Iraq: Pluralism and Culture in Hashemite Iraq. Stanford: Stanford University Press.

Batatu, Hanna. 1978. The Old Social Classes and the Revolutionary Movements in Iraq. A Study of Iraq's Old Landed and Commercial Classes and of its Communists, Ba 'thists and Free Officers. Princeton, NJ: Princeton University Press.

Brancati, Dawn. 2006. "Decentralization: Fueling the Fire or Dampening the Flames of Ethnic Conflict and Secessionism?” International Organization 60 (3): 651-685.

Brubaker, Rogers. 1996. Nationalism Reframed: Nationhood and the National Question in the New Europe. Cambridge: Cambridge University Press.

Buckley-Zistel, Susanne. 2008. Conflict Transformation and Social Change in Uganda: Remembering after Violence. Houndsmills/Basingstoke: Palgrave.

Bunce, Valerie. 1999. Subversive Institutions: The Design and the Destruction of Socialism and the State. Cambridge: Cambridge University Press.

Davis, Eric. 2005. Memories of State: Politics, History, and Collective Identity in Modern Iraq. California: University of California Press.

Dorschner, Jon, and Thomas Sherlock. 2007. "The Role of History Textbooks in Shaping Collective Identities in India and Pakistan." In Teaching the Violent Past: History Education and Reconciliation, edited by Elizabeth A. Cole, 275-315. Lanham, MD: Rowman and Littlefield.

Fischer-Tahir, Andrea. 2012. "Searching for Sense: the Concept of Genocide as Part of Knowledge Production in Iraqi Kurdistan." In Writing the Modern History of Iraq. Historiographical and Political Challenges, edited by Jordi Tejel, Peter Sluglett, Riccardo Bocco, and Hamit Bozarslan, 227-243. Singapore: World Scientific.

Franzén, Johan. 2012. "Writing the History of Iraq: the Fallacy of 'Objective' History." In Writing the Modern History of Iraq. Historiographical and Political Challenges, edited by Jordi Tejel, Peter Sluglett, Riccardo Bocco, and Hamit Bozarslan, 31-45. Singapore: World Scientific.

Gunter, Michael. 2011. The Kurdish Ascending: The Evolving Solution to the Kurdish Problem in Iraq and Turkey. New York: Palgrave Macmillan.

Gunter, Michael, and Mohammed M. A. Ahmed. 2013. The Kurdish Spring. Costa Mesa, CA: Mazda.

Hirst, David. 2013. "This Could Be the Birth of an Independent Kurdish state." The Guardian, January 9. http://www.theguardian.com/commentisfree/2013/jan/09/birth-kurdish-stateottoman-syria-arab-spring.

Kirmanj, Sherko. 2013. "Kurdish Integration in Iraq: The Paradoxes of Nation Formation and Nation Building." In Kurdish Awakening: Nation Building in a Fragmented Homeland, edited by Ofra Bengio, 83-98. Austin, TX: University Texas Press.

Kirmanj, Sherko. 2014. "Kurdish History Textbooks: Building a Nation-state within a Nationstate." Middle East Journal 68 (3): 367-381. doi:10.3751/68.3.12.

Koselleck, Reinhart. 1990. Le Futur passé: contribution à la sémantique des temps historiques [Futures Past: On the Semantics of Historical Time]. Paris: Editions de l'EHESS. 
Kriesberg, Louis. 1998. Constructive Conflicts: From Escalation to Resolution. Lanham, Maryland: Rowman and Littlefield.

Kriesberg, Louis. 2007. "Long Peace or Long War: A Conflict Resolution Perspective." Negotiation Journal 23 (2): 97-116.

Lässig, Simone. 2013. "Introduction: Post-conflict Reconciliation and Joint History Textbook Projects." In History Education and Post-conflict Reconciliation: Reconsidering Joint Textbook Projects, edited by Karina Korostelina and Simone Lässig, 1-13. London: Routledge.

Leach, Fiona, and Mairead Dunne. 2007. "Education, Conflict and Reconciliation: International Perspectives." In Education, Conflict and Reconciliation, edited by Fiona Leach and Mairead Dunne, 11-14. Bern: Peter Lang.

Lederach, John P. 1997. Building Peace: Sustainable Reconciliation in Divided Societies. Washington, DC: United States Institute of Peace Press.

Lowe, Robert, and Gareth Stansfield. 2010. The Kurdish Policy Imperative. Washington, DC: Brookings Institution Press.

Marr, Phebe. 1985. The Modern History of Iraq. Boulder, CO: Westview Press.

Mattes, Robert. 2007. "Democracy without People: Political Institutions and Citizenship in the New South Africa." AfroBarometer, Working Paper 82: 46.

Méténier, Edouard. 2006. "L'historiographie irakienne contemporaine est-elle réductible à un simple discours idéologique? [Can Contemporary Iraqi Historiography be Reduced to a Mere Ideological Discourse?]" In Etats et sociétés de l'Orient arabe en quête d'avenir, 1945-2005 [States and Societies of the Arab Orient in Search of a Future], edited by Gérard D. Khoury and Nadine Méouchy, 261-284, Vol. I. Paris: Geuthner.

Middle East Watch 1993. Genocide in Iraq: The Anfal Campaign Against the Kurds. New York: Human Rights Watch.

Migdal, Joel S. 2001. State in Society Studying How States and Societies Transform and Constitute One Another. Cambridge: Cambridge University Press.

Mitchell, Christopher. 2000. Gestures of Conciliation: Factors Contributing to Successful Olive Branches. New York: St. Martin's Press.

Mlodoch, Karin. 2012. "Fragmented Memory, Competing Narratives.” In Writing the Modern History of Iraq. Historiographical and Political Challenges, edited by Jordi Tejel, Peter Sluglett, Riccardo Bocco, and Hamit Bozarslan, 205-225. Singapore: World Scientific.

Newbury, Catharine. 1988. The Cohesion of Oppression. New York: Columbia University Press.

Osman, Khalil F. 2015. Sectarianism in Iraq: The Making of State and Nation since 1920. New York: Routledge.

Picard, Elizabeth. 2012. "Nation-building and Minority Rights in the Middle East." In Religious Minorities in the Middle East. Domination, Self-Empowerment, Accommodation, edited by Anh N. Longva and Anne S. Roald, 325-349. Leiden, Boston: Brill.

Pingel, Falk. 2008. "Can Truth Be Negotiated? History Textbook Revision as a Means to Reconciliation.' Annals of the American Academy of Political and Social Science 617 (1): 181-198. doi:10.1177/0002716207313087.

Rose, Richard, William, Mishler and Christian, Haerpfer. 1998. Democracy and its Alternatives: Understanding Post-Communist Societies. Baltimore, MD: Johns Hopkins University Press.

Stöber, Georg. 2013. "From Textbooks Comparison to Common Textbooks? Changing Patterns in International Textbook Revision." In History Education and Post-conflict Reconciliation: Reconsidering Joint Textbook Projects, edited by Karina Korostelina and Simone Lässig, 2651. London: Routledge.

Strömbom, Lisa. 2013. Israeli Identity, Thick Recognition and Conflict Transformation. New York: Palgrave Macmillan. 
Tejel, Jordi. 2008. "Urban Mobilization in Iraqi Kurdistan during the British Mandate: Sulaimaniyya, 1918-1930." Middle Eastern Studies 44 (4): 537-552. doi:10.1080/ 00263200802120608.

Torsti, Pilvi. 2007. "How to Deal with a Difficult Past? History Textbooks Supporting Enemy Images in Post-war Bosnia and Herzegovina." Journal of Curriculum Studies 39 (1): 77-96. doi:10.1080/00220270600765278.

UNESCO. 2012. Iraqi Curriculum Framework. Amman: UNESCO.

Valls, Rafael. 2007. "The Spanish Civil War and the Franco Dictatorship: The Challenges of Representing a Conflictive Past in Secondary Schools." In Teaching the Violent Past: History Education and Reconciliation, edited by Elizabeth A. Cole, 155-174. Lanham, MD: Rowman and Littlefield.

Wing, Joel. 2012. "Majority of Iraqi Kurds Support an Independent Kurdistan: New Poll." Ekurd, October 3. http://www.ekurd.net/mismas/articles/misc2012/9/state6519.htm.

JORDI TEJEL is Research Professor in the Department of International History at Graduate Institute of International and Development Studies.

ADDRESS: Department of International History, Graduate Institute of International and Development Studies, Geneva, CP 136, 1211 Geneva 21, Switzerland. Email: Jordi.Tejel@graduateinstitute.ch 